\title{
SITE INFLUENCE ON THE MORPHOLOGICAL, PHYSICAL AND MECHANICAL PROPERTIES OF GIANT BAMBOO (DENDROCALAMUS ASPER) IN BUKIDNON PROVINCE, MINDANAO, PHILIPPINES
}

\author{
Aguinsatan RG', Razal RA ${ }^{2, *}$, Carandang $\mathbf{M G}^{3}$ \& Peralta $\mathbf{E K}^{4}$ \\ ${ }^{1}$ Graduate Student, University of the Philippines Los Baños and Assistant Professor, Central Mindanao University, Musuan, \\ Maramag, Bukidnon, 8710 Philippines \\ ${ }^{2}$ Professor, Forest Products and Paper Science Department, College of Forestry and Natural Resources, University of the \\ Philippines Los Baños, Laguna, 4031 Philippines \\ ${ }^{3}$ Professor, Institute of Renewable Natural Resources, College of Forestry and Natural Resources, University of the Philippines \\ Los Baños, Laguna, 4031 Philippines \\ ${ }^{4}$ Professor, Institute of Agricultural Engineering, College of Engineering and Agro-Industrial Technology, University of the \\ Philippines Los Baños, Laguna, 4031 Philippines \\ *rarazal@up.edu.ph
}

Submitted September 2017; accepted June 2018

\begin{abstract}
Bamboo is known for its versatility and adaptability with many potential uses. However, there is very limited information on the influence of the conditions of growth site on the properties of bamboo poles. This study was done to compare selected morphological, physical and mechanical properties of Giant bamboo (Dendrocalamus asper) growing in two different sites - along a river bank (riparian) and in upland areas (far from a water body). Eighteen culms of 3-4 years old Giant bamboo were randomly selected and harvested from three clumps, in each of the two predetermined sites in the province of Bukidnon, Mindanao Island, Philippines. Results showed that, on average, upland bamboos had higher specific gravity, thinner culm wall and lower moisture content (MC) than riparian bamboo. The bending strength of the culms from the two sites was consistent with the physical properties trend, with the poles grown in upland sites being better in bending than poles in riparian sites. Statistically, only the MC, culm wall thickness, specific gravity, volumetric shrinkage and swelling, and radial swelling were significantly different between the riparian and upland bamboo poles. The study's findings attest to the influence of growth site as a factor that could affect some of the morphological and physical properties of Giant bamboo.
\end{abstract}

Keywords: Culm wall, riparian, upland, specific gravity, radial shrinkage, radial swelling, volumetric shrinkage, bending strength, moisture content

\section{INTRODUCTION}

Bamboo was considered as a minor forest product until its recent emergence as an important non-timber resource that can substitute wood in many applications. There is now increasing attention given to bamboo for its economic and environmental benefits (Zhou et al. 2005). Traditionally, bamboo has been used for house construction, furniture and handicraft making, and for food preparation and cooking. In recent years, the bamboo culm has been processed into a diversity of products ranging from domestic household products to other industrial uses (Malanit et al 2008, Chaowana 2013). Increasingly, the bamboo culm either in solid or modified form, has been employed in modern construction and as structural materials for bridges, water transportation facilities and skyscraper scaffoldings (Chaowana 2013). The extension in the uses of bamboo to industrial applications has been made possible through advances in processing technology and increased market demand (Falayi et al. 2014). In addition, bamboo has also been used for ornamental purposes, as a landscaping material, and as a reforestation species to help control erosion and stabilise river banks (Tesoro \& Espiloy 1988).

In Philippines, bamboo has become one of the vital and unique components of forestry 
and is now recognised for its significant role in ecological improvement, sustainable development and poverty alleviation (Bareja 2010). The Department of Environment and Natural Resources (DENR) in the Philippines has included bamboo among the forest species to be planted under the National Greening Program.

There are 70 known species of bamboo in the Philippines (Aggangan 2015). Only 9 species which include Giant bamboo (Dendrocalamus asper) are considered economically important (PCARRD 1991, Virtucio \& Roxas 2003, Razal \& Palijon 2009). Giant bamboo is the most commercially important bamboo species in Northern Mindanao, produced to supply the region with tomato stakes, poultry floors and engineered bamboo products (Decipulo et al. 2009). It was first introduced in Bukidnon by the Ecosystems Research and Development Service in the DENR Bambusetum in Malaybalay City (Alipon et al. 2011).

Giant bamboo grows in almost all types of soil from low altitudes up to $1,500 \mathrm{~m}$ above sea level (Dransfield \& Widjaja 1995, Rojo et al. 2000). It has been recommended in environmental and livelihood programs in Philippines due to its various ecological, economic and social benefits (Toledo-Bruno et al. 2017). Its versatility and adaptability to all sorts of climate zones and soil types prompted studies on its physical and mechanical properties that could affect many of its uses.

Bamboo obtained along river banks had high moisture content (MC), and consequently, drying took longer than bamboo poles obtained from non-riparian locations. Additionally, processed bamboo products such as chopsticks and barbecue sticks from bamboo grown along river banks were more prone to breakage during processing.

Thus, this study was prompted to verify the bamboo products, as well as to provide scientific basis for the difference in properties. Hence, the main purpose of the study is to compare selected morphological, physical and mechanical characteristics of Giant bamboo growing in two different sites: riparian (along river bank) and upland areas (far from water body). The findings would explain the observed differences in processing characteristics of bamboo from different sites, and enable planters to consider proximity to water bodies as a choice of planting sites for industrial bamboo. The findings will also guide manufacturers in using site origin as a basis for grading and choosing raw materials for their processing operations.

\section{MATERIALS AND METHODS}

Giant bamboo culms used in this study were harvested in August 2016 from a plantation within the landholdings of Central Mindanao University in Musuan, Maramag, Bukidnon, Philippines. Selected culms were obtained from two different sites within the same plantation. One was the riparian area (along a river bank) and the other was an upland area which was far $(>100 \mathrm{~m})$ from a water body. The study sites are located at latitude $7^{\circ} 51^{\prime}$ and $7^{\circ} 52^{\prime} \mathrm{N}$, and at longitude $125^{\circ} 2^{\prime}$ and $125^{\circ} 3 ' \mathrm{E}$, which are 313 and 393 meters above sea level for the riparian and upland sites, respectively. Culms, between 3-4 years in age were randomly chosen from three selected clumps in each site. Culm age was determined by the features, as described by Virtucio \& Roxas (2003). A total of 18 culms of varied diameter and wall thickness were used in the study (3 culms per clump, 3 clumps per site). After measuring the total length, a $3 \mathrm{~m}$ long pole was cut $2 \mathrm{~m}$ from the base of each culm (Figure 1). Two specimens, $2.54 \mathrm{~cm}$ in length (a total of 36 subsamples), were cut from the upper and lower end of the $3 \mathrm{~m}$ pole for green $\mathrm{MC}$ determination. The MC specimens were placed in polyethylene bags to prevent drying during transport. Upon reaching the laboratory, the culm wall thickness was measured with a digital Vernier caliper, and each sample was weighed using an electronic weighing balance. The specimens were oven dried at a temperature of $103 \pm 2{ }^{\circ} \mathrm{C}$ until constant weights were achieved. Meanwhile, the remainder of the $3 \mathrm{~m}$ long pole was air dried for three months, in preparation for physical properties and static bending tests.

\section{Physical properties}

The physical properties determined included specific gravity, shrinkage and swelling (volumetric, across the culm wall or the radial direction, along the culm circumference or tangential direction, and along the longitudinal direction). In the absence of a standard procedure for bamboo, test specimens were prepared based on Standard Test Methods for Small Clear 


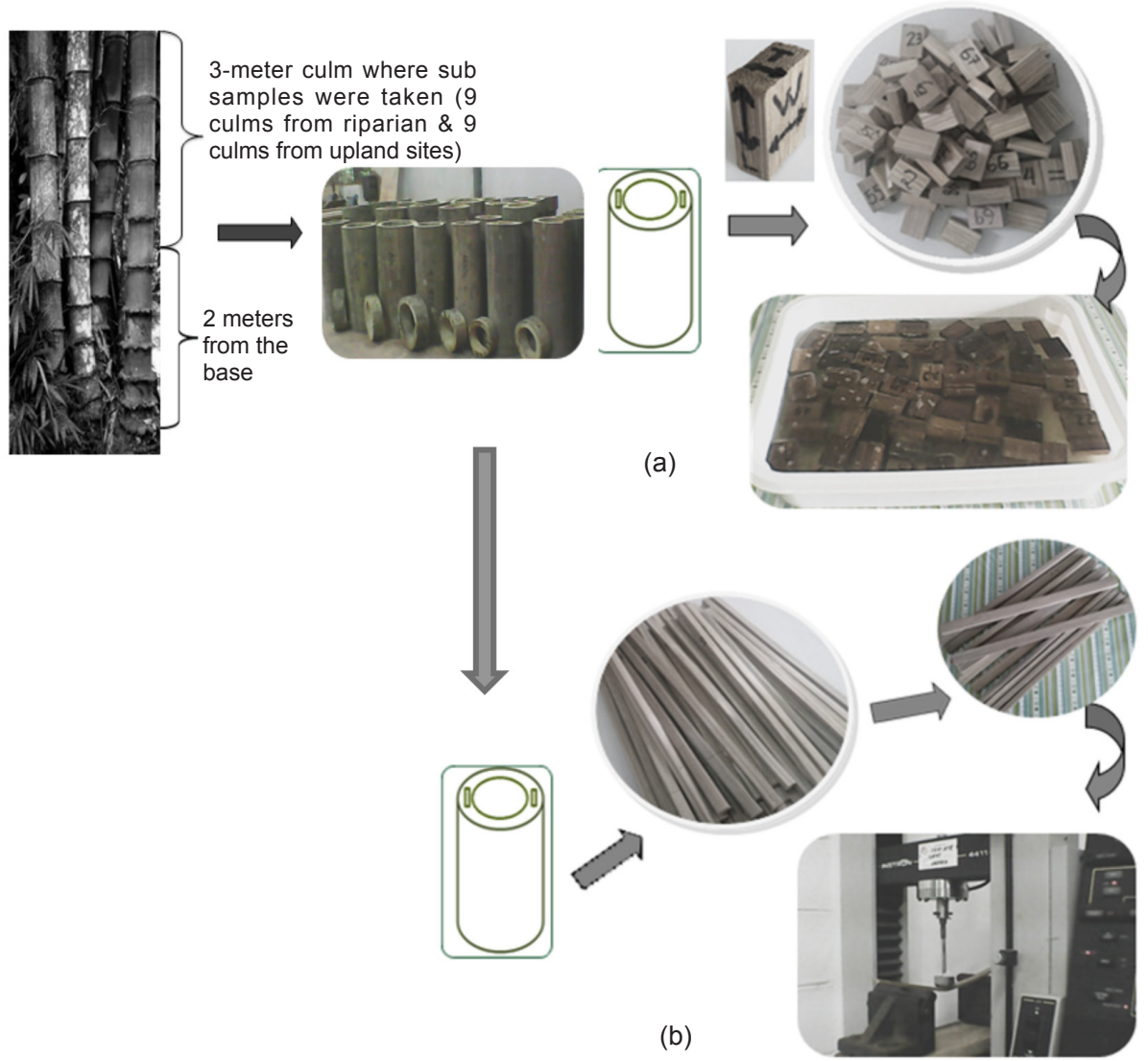

Figure 1 Schematic diaggram showing the sampling scheme and cutting of specimens in preparation for (a) physical and (b) mechanical properties tests; the dimensions/orthotropic measurements are indicated as $(\mathrm{T})$ thickness across the culm wall or radial (L) longitudinal and (W) sample width along the circumference of the culm wall or tangential dimension

Specimens of Timber (ASTM D143-94 2000) with modifications as described below.

For the determination of specific gravity, percent shrinkage and swelling, 72 rectangular (3 cm long, $2 \mathrm{~cm}$ wide and $1 \mathrm{~cm}$ thick, taken from the central portion of the culm wall) specimens were obtained from the internode (Figure 1a) with two sub-samples being taken from both the upper and lower portion of each $3 \mathrm{~m}$ pole. Dimensions of the rectangular airdried specimens (at 16\% MC) were measured with the use of a digital Vernier caliper up to an accuracy of $0.001 \mathrm{~mm}$. The specimens were first weighed before drying in an oven for 24 hours at a temperature of $103 \pm 2^{\circ} \mathrm{C}$. When dried, dimensions of the samples were taken at $0 \% \mathrm{MC}$. The volumetric shrinkage and shrinkage along the longitudinal direction and across the culm wall from $16-0 \% \mathrm{MC}$ were calculated.

After weighing and taking the measurements of the oven dried samples, swelling test followed. The same specimens were soaked in distilled water until they were fully submerged at the bottom of the container (Figure 1a). The swollen specimens were removed from the container and placed momentarily over an absorbent cloth to remove excess water on the surface, before measurements were carried out. Percentage volumetric swelling, across the culm wall, along the circumference, and in the longitudinal direction was determined from oven-dry condition $(0 \% \mathrm{MC})$ to full moisture absorption point (until specimens sank at the container bottom).

\section{Static bending properties}

For the static bending test, eighteen node-free specimens, each measuring $6 \mathrm{~mm} \times 15 \mathrm{~mm} \times$ $300 \mathrm{~mm}$ were prepared, corresponding to 9 samples per site. As indicated above, the poles were cut $2 \mathrm{~m}$ above the base, from lower portion of the culms. The test was carried out in an INSTRON 4411 model universal testing 
machine. Load cell used was $5 \mathrm{kN}$ and the speed of loading was $5 \mathrm{~mm}$ per minute, according to the method by Abang-Abdullah (1984), with some modification on the length of the test span under three-point loading. The actual test span length (distance between the two supports) used was 210 millimeters.

Modulus of elasticity (MOE) was computed with the deflection $(\delta)$ for bending assuming a simply supported concentrated load (Equation 1).

$$
\begin{aligned}
\text { MOE } & =\frac{\mathrm{P} \times \mathrm{L}^{3}}{48 \times 1 \times \delta} \\
& =\frac{\mathrm{b} \times \mathrm{d}^{3}}{12} \\
& =[(\mathrm{P} \times \mathrm{L} 3) /(48 \times \mathrm{E} \times \mathrm{I})]
\end{aligned}
$$

where

$$
\begin{aligned}
\mathrm{P}= & \text { load } / \text { breaking load in kilo Newton } \\
& (\mathrm{kN}) \\
\mathrm{L}= & \text { length of the beam/ distance between } \\
& \text { knife edges on which the sample is } \\
& \text { supported }(\mathrm{mm}) \\
\mathrm{I}= & \text { moment of inertia } \mathrm{mm}^{4} \\
\mathrm{~b}= & \text { breadth/width }(\mathrm{mm}) \\
\mathrm{d}= & \text { depth/thickness }(\mathrm{mm}) \\
\delta= & \text { deflection }
\end{aligned}
$$

The Modulus of Rupture (MOR) was computed using Equation 2 based on the recorded maximum load data at which breakage of the sample under test occurred.

$$
\mathrm{MOR}=\frac{3 \times \mathrm{P} \times \mathrm{L}}{2 \times \mathrm{b} \times \mathrm{d}^{2}}
$$

where

$$
\begin{aligned}
\mathrm{P}= & \text { load/breaking load in kilo Newton }(\mathrm{kN}) \\
\mathrm{L}= & \text { length of the beam/ distance between } \\
& \text { knife edges on which the sample is } \\
& \text { supported }(\mathrm{mm}) \\
\mathrm{b}= & \text { breadth/width }(\mathrm{mm}) \\
\mathrm{d}= & \text { depth/thickness }(\mathrm{mm})
\end{aligned}
$$

\begin{tabular}{|c|c|c|c|c|c|c|c|c|c|c|}
\hline Clump No. & & 1 & & & 2 & & & 3 & & Average \\
\hline Culm No. & 1 & 2 & 3 & 1 & 2 & 3 & 1 & 2 & 3 & \\
\hline Site & \multicolumn{10}{|c|}{ Total length (m) } \\
\hline Riparian & 24.8 & 17.1 & 22.2 & 17.9 & 23.8 & 26.0 & 19.8 & 20.6 & 23.6 & $21.76^{\mathrm{a}^{*}}(3.1)^{* *}$ \\
\hline Upland & 21.7 & 22.6 & 24.8 & 26.2 & 22.9 & 20.8 & 21.7 & 21.8 & 27.1 & $23.29^{\mathrm{a}}(2.2)$ \\
\hline \multicolumn{11}{|c|}{ Culm Diameter (cm) } \\
\hline Riparian & 13.1 & 11.6 & 10.2 & 11 & 13.8 & 14.2 & 10.9 & 12.4 & 11.6 & $12.09^{\mathrm{a}}(1.4)$ \\
\hline Upland & 11.1 & 12.5 & 13.7 & 14.9 & 12.2 & 13.8 & 12 & 10.9 & 13.9 & $12.78^{\mathrm{a}}(1.4)$ \\
\hline \multicolumn{11}{|c|}{ Culm Wall Thickness (mm) } \\
\hline Riparian & 21 & 18 & 19 & 19 & 20 & 18 & 20 & 22 & 22 & $19.89^{\mathrm{a}}(1.5)$ \\
\hline Upland & 12 & 16 & 21 & 19 & 19 & 19 & 17 & 15 & 17 & $17.22^{\mathrm{b}}(2.7)$ \\
\hline \multicolumn{11}{|c|}{ Moisture content (\%) } \\
\hline Riparian & 93 & 100 & 112 & 100 & 120 & 118 & 89 & 96 & 122 & $105.6^{\mathrm{a}}(12.4)$ \\
\hline Upland & 77 & 74 & 93 & 74 & 78 & 81 & 103 & 81 & 73 & $81.5^{\mathrm{b}}(9.9)$ \\
\hline
\end{tabular}

\section{Statistical analysis}

A t-Test (two-sample assuming unequal variances) was done to compare the means of the studied variables (replicated three times) using Microsoft excel.

\section{RESULTS AND DISCUSSION}

\section{Morphological characteristics}

The morphological characteristics of $D$. asper culm samples that were included in the study were the total culm length or height, culm diameter and culm wall thickness. Likewise, the green MC of the freshly-cut bamboo culms was also determined. Individual measurements and the average values of these properties are shown in Table 1. Statistically, only the differences in

Table 1 Morphological characteristics and moisture content of Dendrocalamus asper measured at green condition

*Figures with the same letters are not significantly different, $\mathrm{p}<0.05$; ** numbers in parenthesis refer to the standard deviation 
culm wall thickness and MC were found to be significant. Other variables observed were not statistically different although on average, the poles growing away from the river were longer and had bigger diameter. Measurement results indicate that Giant bamboo poles harvested from riparian site had $15 \%$ thicker culm wall $[19.9 \mathrm{~mm}$ (1.5) vs.17.2 mm (2.7) for riparian and upland, respectively] and had MCs that were on average, $30 \%$ higher than upland site. The MC of riparian bamboo poles ranged from 89 to $122 \%$ (with a mean of $106 \pm 12 \%$ ) when compared to the MC of upland bamboo poles, whose MC ranged from 73 to $103 \%(82 \pm 10 \%)$.

The results showed that growing closer to a river enables the bamboo to access more water which are held up in the culms. The availability of water possibly contributes to its more vigorous growth, resulting in thicker culm walls and bigger diameter. This corroborates the study of Gnanaharan (1994) who found that Dendrocalamus strictus growing in moist areas in Kerala, India had longer internodes and larger diameter. The higher MC of riparian poles also suggests that the bamboo culms near the river banks have more parenchyma cells. According to Liese (1998), parenchyma cells have higher water holding capacity than other cell types in bamboo, hence, they are responsible for storing more moisture in the culms growing nearer to the river. The thicker culm walls of the bamboo and the lower specific gravity observed in riparian sites can be related to the presence of more parenchyma cells. These observations are supported by the findings in previous studies (Espiloy \& Sasondoncillo 1978, Yu et al. 2008), which found higher specific gravity in portions of the culm that have thinner walls.

\section{Physical properties}

\section{Specific gravity or relative density}

The average specific gravity of the $D$. asper determined after air drying (approximately with $16 \% \mathrm{MC}$ ) was $0.582 \pm 0.053$ and $0.644 \pm$ 0.043 for those harvested in riparian and upland areas, respectively (Figure 2). After oven drying, the average specific gravity was $0.636 \pm 0.058$ for the riparian poles and $0.713 \pm 0.047$ for poles from the upland areas. The results were within the range of the specific gravity values of Giant bamboo and other species reported in literature (Table 2). The findings of the study showed that site had influence on the specific gravity of Giant bamboo. Upland bamboo had higher specific gravity than riparian bamboo $(p<0.05)$. The current study's observation showed that the upland Giant bamboo poles had thinner culm walls than those along riparian sites. The results appeared to corroborate previous findings that thinner culm walls correspond to higher specific gravity. Such increase in specific gravity is attributed to the preponderance of

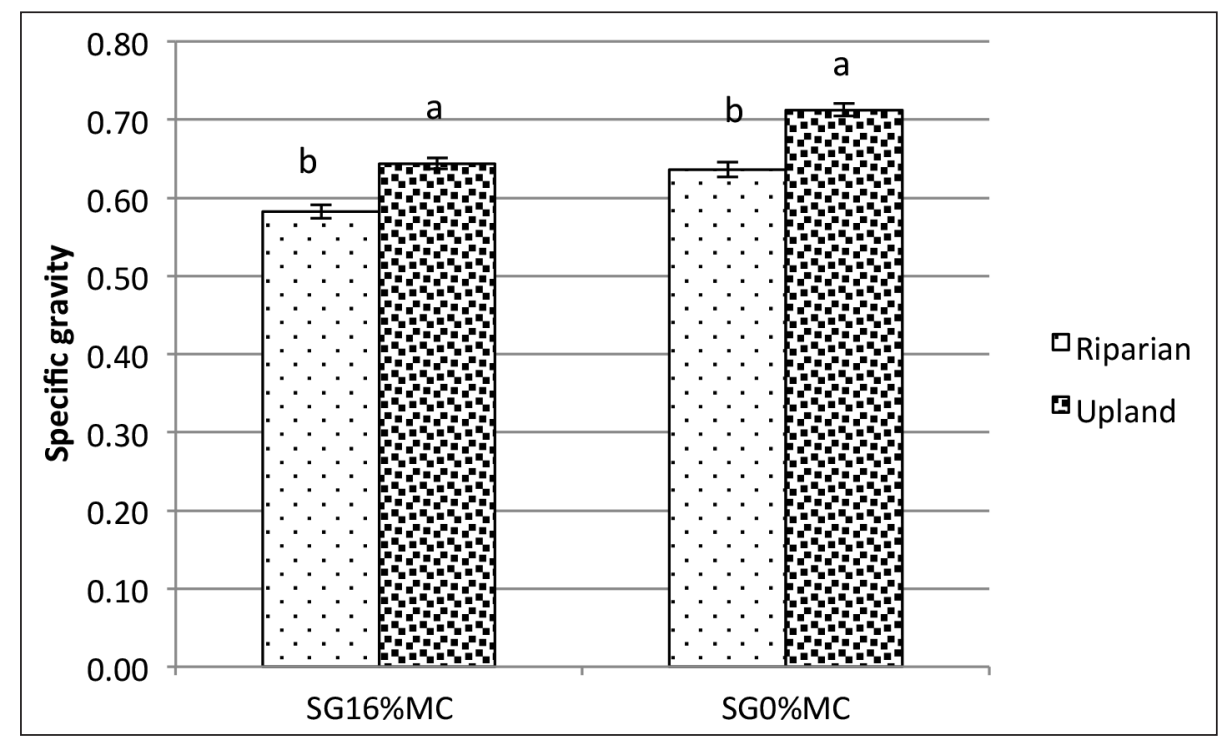

Figure 2 Specific gravity (36 samples per site) at air dry condition $\left(\mathrm{SG}_{16 \% \mathrm{MC}}\right.$ ) and after oven drying $\left(\mathrm{SG}_{\%} \mathrm{MC}_{\mathrm{C}}\right.$; figures with the same letters are not significantly different, $\mathrm{p}<0.05$ 
Table 2 Specific gravity of Dendrocalamus asper and other bamboo species as reported in literature

\begin{tabular}{lcl}
\hline Species & Specific gravity & \multicolumn{1}{c}{ Reference } \\
\hline Not specified & 0.50 to 0.90 & Beldean et al. (2016) \\
Not specified & 0.40 to 0.80 & Li (2004) \\
Not specified & 0.50 to 0.80 & Liese (1985) \\
Dendrocalamus asper & 0.55 to 0.90 & Malanit et al. (2008) \\
Dendrocalamus asper & 0.70 & Dransfield \& Widjaja (1995) \\
Dendrocalamus asper & 0.67 & Othman et al. (1995) \\
Dendrocalamus asper & 0.77 & Pakhkeree (1997) \\
Phyllostachys bambusoides & 0.52 & Lee et al. (1994) \\
\hline
\end{tabular}

vascular bundles in thin culm walls (Grosser \& Liese 1971, Liese 1998). As observed by Liese $(1985,1998)$, there is less parenchymatous tissue in the inner portion of thin culm wall but there are more vascular bundles and fibers per unit area. Likewise, Malanit et al. (2008) observed that fiber content is positively correlated with specific gravity.

\section{Dimensional stability (shrinkage and swelling)}

The dimensional stability of a material is very important when it is used as a substitute for wood. In bamboo, as in wood, dimensional stability is indicated by the shrinkage that occurs when water molecules bound to the cell wall are lost as drying ensues. Shrinkage is a problem that occurs during drying of culms and during their service life (Liese \& Kohl 2015). In bamboo, shrinkage varies along the different orthotropic directions (Chaowana 2013). Swelling, on the other hand, usually occurs when the material is exposed to moisture or it comes in contact with water.

Figure 3 summarises the results of (a) shrinkage and (b) swelling tests done on the bamboo samples. Except for volumetric shrinkage, where riparian bamboo shrank slightly more $(8.48 \% \pm 0.31)$ than upland bamboo $(8.32 \% \pm 0.44)$, shrinkage across the culm wall (radial), along the circumference of the culm (tangential) and along length (Figure 3a) were not statistically different. For swelling tests results (Figure 3b), riparian bamboo was more prone to swelling (volume and along culm wall thickness) as it reabsorbed water than the upland bamboo. Volumetric swelling for riparian bamboo poles averaged $18.68 \pm$ $2.17 \%$ while that of upland poles was $14.84 \pm$ $1.43 \%$. Radial swelling averaged $11.66 \pm 0.85 \%$ and $8.31 \pm 0.63 \%$ for riparian and upland poles, respectively. Note that for both shrinkage and swelling, changes in the longitudinal direction were almost negligible, consistent with observations in previous studies (Espiloy \& Sasondoncillo 1978, Yu et al. 2008).

The slight difference observed in shrinkage and swelling in riparian poles compared to upland poles appeared to support the manufacturer's observation that riparian poles were more prone to dimensional changes than upland poles. In wood, dimensional stability is related to specific gravity, where higher shrinkage and swelling are generally associated with high specific gravity. However, this trend is not necessarily observed in bamboo, which has high oven dry density and not necessarily the highest shrinkage in radial and tangential directions (Abd-Latif \& Liese 1995). These can be partly explained by the anatomical features of bamboo that are different from that of wood. The absence of wood rays in bamboo, for instance, explains why shrinkage anisotropy is less in bamboo than in wood (Liese \& Tang 2015).

\section{Static bending properties}

Bamboo possesses excellent mechanical properties (Liese 1985, Wang et al. 2014, Yu 2007). Its inherent strength has enabled its use as a standard building material for many centuries (Bamboo-Botanicals 2017). Mechanical properties of bamboo are correlated with specific gravity, i.e., the higher the specific gravity, the stronger the bamboo (Liese 1985). The MOR and MOE significantly depend on specific gravity (Malanit et al. 2008). Such variation could also be affected by environmental factors like site condition (Abd-Latif \& Liese 2002). The latter study found culm characteristics in Bambusa vulgaris and Gigantochloa schortechinii to vary significantly with site. 

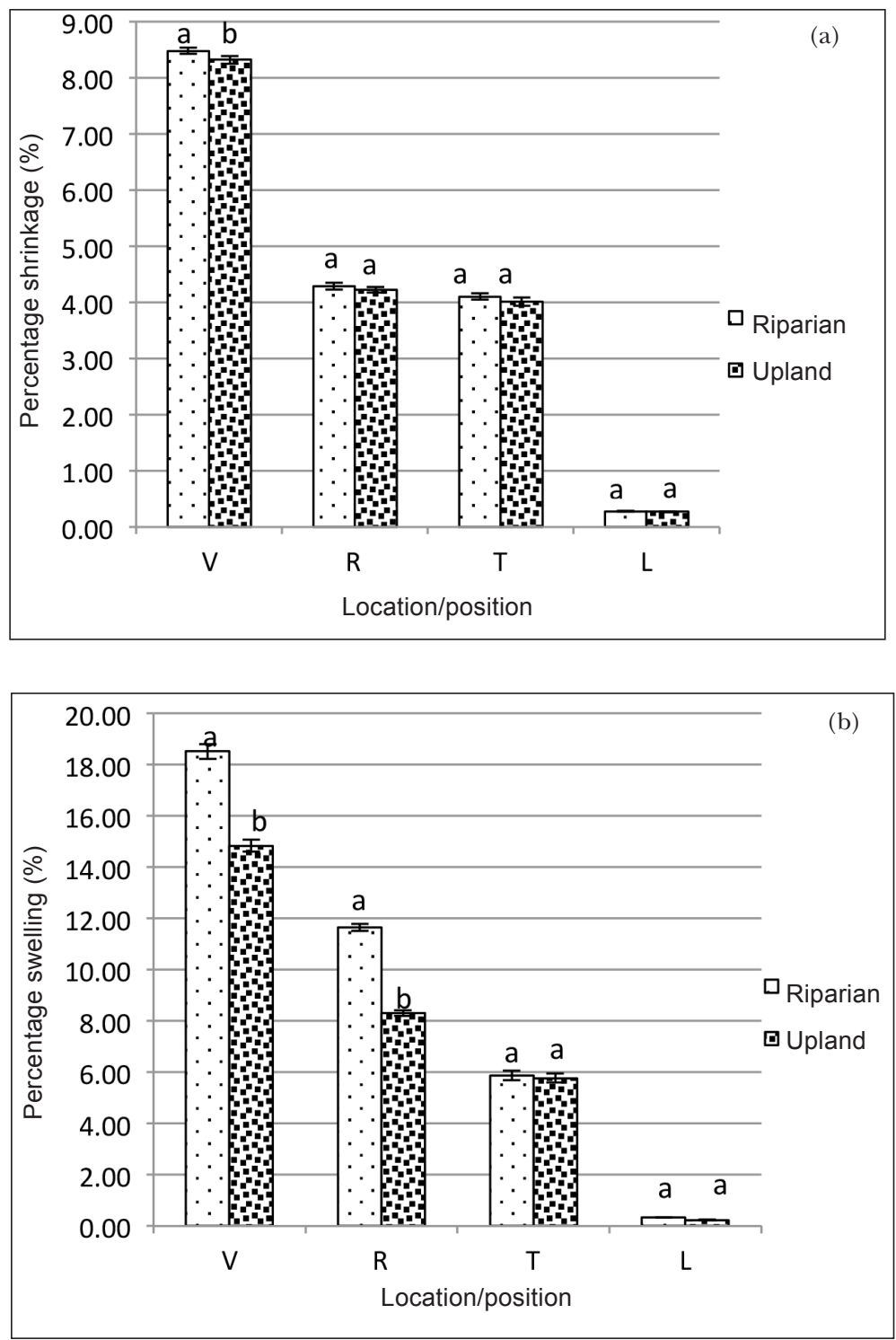

Figure 3 Comparison of the percentage of (a) shrinkage and (b) swelling for 36 samples showing the difference in volume $(\mathrm{V})$, and dimensions in radial $(\mathrm{R})$, tangential $(\mathrm{T})$ and along the longitudinal direction $(\mathrm{L})$ between riparian and upland bamboo; figures with the same letters are not significantly different, $\mathrm{p}<0.05$

In the current study, MOE in bending of giant bamboo poles harvested from the upland site was $20 \%$ higher than those in the riparian sites, with average values of $11.68 \pm 2.05$ and $9.72 \pm$ $1.39 \mathrm{GPa}$, respectively. For the MOR in bending, the corresponding average values were 106.43 $\pm 11.03 \mathrm{MPa}$ for the riparian bamboo poles and 135.56 20.83 MPa for the upland poles (Figure 4 ). This showed that bamboos growing in areas farther away from bodies of water tend to be mechanically stronger than those grown along riparian areas. These results concurred with the findings of Gnanaharan (1994) who made almost similar observations on Dendrocalamus strictus growing in Kerala, India. Gnanaharan (1994) found that culms from moist areas in Kerala (India) had lower MOR and MOE than culms from dry areas. Similarly, Soeprayitno et al. (1990) observed higher bending and tensile strengths of Gigantochloa pseudoarundinacea poles harvested from slopes than those from valleys. The results substantiate Liese (1985) assertion that higher density and increased strength properties may occur in drier areas and on slopes. The static bending test results were consistent with the observations on the specific gravity of the bamboo poles, which was found to be higher in the upland poles than those grown in riparian areas. 

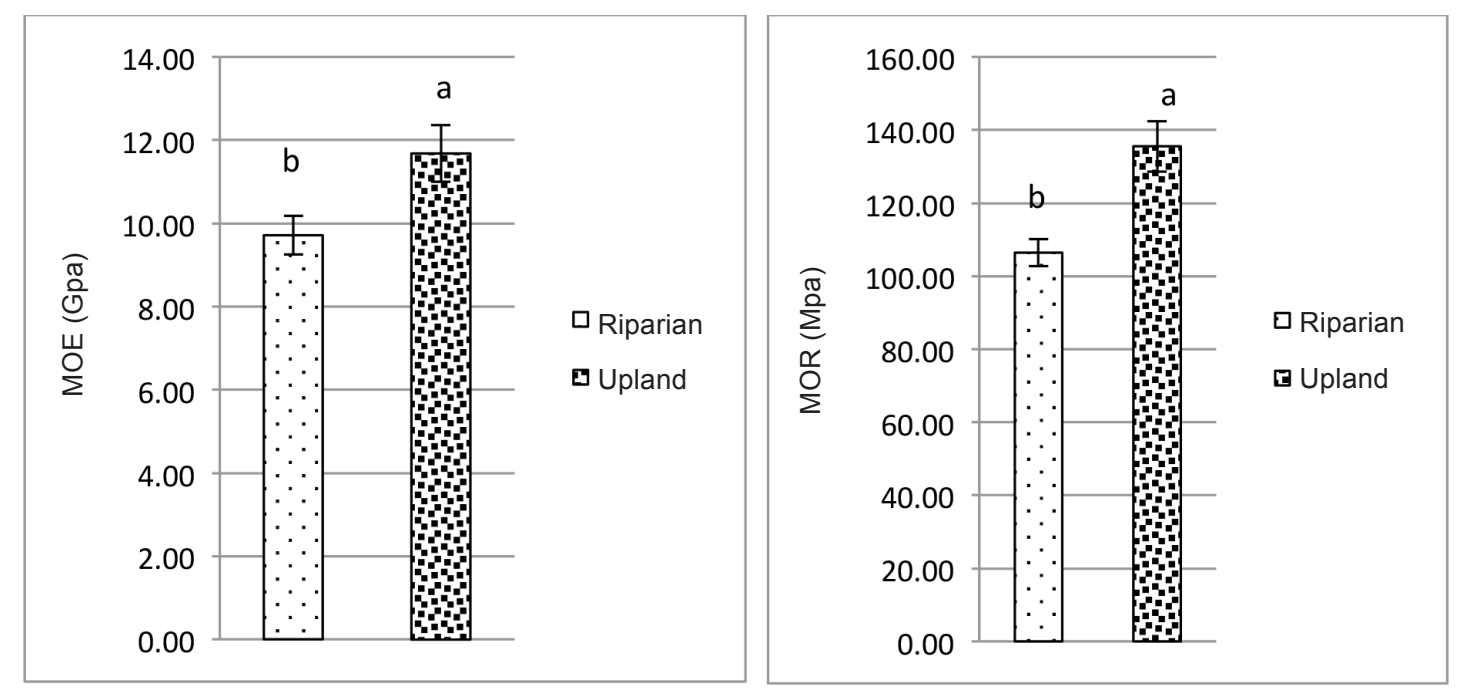

Figure 4 Modulus of elasticity (MOE) and modulus of rupture (MOR) under static bending of Giant bamboo poles from riparian and upland sites in Bukidnon, Philippines; figures with the same letters are not significantly different, $\mathrm{p}<0.05$

\section{CONCLUSIONS}

This study validates that bamboo harvested from areas away from a water body tends to have lower MC, higher specific gravity and are relatively stronger than bamboo obtained from generally moist soil, as those found along riparian areas. Statistically, only MC and culm wall thickness were significantly different, while the other morphological parameters were not. The study also revealed that upland bamboos had greater dimensional stability than those harvested from riparian area. Poles from upland sites also had higher MOE and MOR in bending. These findings were supported by the low MC and high specific gravity of upland culms, which are the most important physical properties affecting strength. Therefore, site which affects some of the bamboo's morphological, physical and mechanical characteristics, as shown in the study, is an important factor to be considered in the development and management of bamboo plantations, and the utilisation and processing of bamboo poles for its intended uses. Failure to consider site conditions, particularly the proximity of planting site to a river, may lead to bamboo poles with properties that do not meet the requirements of the desired bamboo products.

\section{ACKNOWLEDGMENTS}

The authors would like to acknowledge Pajares M, Aguinsatan A, Serrano C, de Alday M and Cerna J for assisting in securing, preparing and testing the bamboo samples, and analysing the test results. The primary author also wishes to thank the Central Mindanao University for the scholarship that enabled her to pursue graduate studies at the University of the Philippines Los Baños.

\section{REFERENCES}

Abang-Abdullah AA. 1984. Development of basic mechanical tests for Malaysian bamboos. Pertanika 7: 13-17.

Abd-Latif M \& Liese W. 1995. Utilization of bamboo. Pp 50-102 in Razak AO et al. (eds) Planting and Utilization of Bamboo in Peninsular Malaysia. Research Pamphlet No. 118. Forest Research Institute of Malaysia, Kepong.

Abd-Latif M \& Liese W. 2002. Culm characteristics of two bamboos in relation to age, height and site. Pp 223233 in Kumar AI et al. (eds) Bamboo for Sustainable Development - Proceedings of the Vth International Bamboo Congress and the VIIth International Bamboo Workshop. 2-6 November 1998, San Jose.

Alipon MA, Bondad EO, Sapin GN \& Exconde AB. 2011. Comparative physical and mechanical properties Giant bamboo [Dendrocalamus asper (Schultes f.) Backer ex Heyne] from Malaybalay, Bukidnon (Region XI) and Mt. Makiling, Laguna (Region IVA). Philippine Forest Products Journal 2: 84-98. 
ASTM D143-94. 2000. Standard Test Methods for Small Clear Specimens of Timber. ASTM International, West Conshohocken.

Aggangan R. 2015. The Philippine bamboo industry: Issues, potentials, strategies and action programs. Paper presented at the World Bamboo Congress, Damyang.

Bamboo-Botanicals. 2017. Interesting bamboo facts. http:/ / www.bamboobotanicals.ca/html/about-bamboo/ bamboo-facts.html.

BAREJA BG. 2010. Growing bamboo is a promising crop farming venture. http://www.cropsreview.com/ growing-bamboo.html.

Beldean E, Timar M \& Porojan M. 2016. Bamboo - A Challenging Material for Romanian Engineers. Part 1: Understanding the Material. Bulletin Series II: Forestry, Wood Industry, Agricultural Food Engineering, Volume 9, No. 1. Transilvania University of Brasov, Brasov.

Chaowana P. 2013. Bamboo: An alternative raw material for wood and wood-based composites. Journal of Materials Science Research 2. doi:10.5539/jmsr.v2n2p90.

Decipulo MS, OCKerby S \& Midmore DJ. 2009. Managing clumps of Dendrocalamus asper in Bukidnon, Philippines. Pp 36-45 in Midmore DJ (ed) Proceedings of a Workshop on the Silvicultural Management of Bamboo in the Philippines and Australia for Shoots and Timber. ACIAR Proceedings 129. 22-23 November 2006, Los Baños.

Dransfield S \& Widjaja E. 1995. Plant Resources of South-East Asia No. 7: Bamboos. Backhuys Publishersa, Leiden.

EsPILOY ZB \& SASONDONCILLO RS. 1978. Some characteristics and properties of Giant bamboo. FORPRIDE Digest 7: $34-46$.

FALAyI FR, SOYoye BO \& Tehinse T. 2014. The influence of age and location on selected physical and mechanical properties of bamboo (Phyllostachys pubescens). International Journal of Research in Agriculture and Forestry 1: 44-54.

Gnanaharan R. 1994. Physical and strength properties of Dendrocalamus strictus grown in Kerala, India. Pp 188-192 in Bamboo in Asia and the Pacific: Proceedings of the 4th International Bamboo Workshop. FORSPA Publication 6 IDRC FAO-UNDP, 27-30 November 1991, Chiangmai.

Grosser D \& Liese W. 1971. On the anatomy of Asian bamboos, with special reference to their vascular bundles. Wood Science and Technology 5: 290-312.

Lee AWC, Xuesong B \& Perry NP. 1994. Selected physical and mechanical properties of giant timber bamboo grown in South Carolina. Forest Product Journal 44: 40-46.

Liese W. 1985. Anatomy and properties of bamboo. Pp 196-208 in Rao AN et al. (eds) Proceedings of the International Bamboo Workshop. 6-14 October, Hangzhou.

LIESE W. 1998. Anatomy of Bamboo Culms. Chapter 5. Technical Report No.18. International Network for Bamboo and Rattan, Beijing.

Liese W \& Kohl M. 2015. Bamboo: The Plant and Its Uses. Technology and Engineering. Springer-Verlag, New York.

Liese W \& TANG TKH. 2015. Properties of the bamboo culm. Pp. 227-256. In Liese W \& M. Köhl (eds) Bamboo the Plant and Its Uses. Springer, Switzerland.
Li X. 2004. Physical, chemical and mechanical properties of bamboo and its utilization potential for fiberboard manufacturing. MSc Thesis. Louisiana State University, Louisiana.

Malanit P, Barbu MC, Liese W \& Frühwald A. 2008. Macroscopic aspects and physical properties of Dendrocalamus asper Backer for composite panels. Journal of Bamboo and Rattan 7: 151-163.

Othman AR, Mohmod AL, Liese W \& Haron N. 1995. Planting and Utilization of Bamboo in Peninsular Malaysia. Research Pamphlet No. 118. Forest Research Institute Malaysia, Kepong.

PCARRD 1991. The Philippine Recommends for Bamboo Production. PCARRD Philippine Recommends Series No. 53-A. College, Laguna.

Razal RA \& Palijon AM. 2009. Non-Wood Forest Products of the Philippines. College of Forestry and Natural Resources, University of the Philippines, Los Baños, College, Laguna.

Rojo JP, Roxas CA, Pitargue Jr FC \& Brinas CA. 2000. Philippine Erect Bamboo Species: A Field Identification Guide. Forest Products Research and Development Institute, Los Baños.

PAKhKeree T. 1997. Physical and mechanical properties of Dendrocalamus asper Backer. MSc Thesis, Kasetsart University, Thailand.

Soeprayitno T, Tobing TL \& Widjaja E. 1990. Why the Sundanese of West Java prefer slope-inhabiting Gigantochloa pseudoarundinaceae to those growing in the valley. Pp 215-217 in Ramanuja $\mathrm{R}$ et al. (eds) Bamboos: Current Research. Proceedings of the International Bamboo Workshop, 14-18 November 1988, Cochin.

Tesoro FO \& Espiloy Z. 1988. Bamboo research in the Philippines. Pp 15-19. Proceedings of the International Bamboo Workshop on Nov. 14-18. Los Baños.

Toledo-Bruno AG, Marin RA, Medina MAP, Puno GR, Villarta RO \& Puno RR. 2017. Ecology of litterfall production of giant bamboo Dendrocalamus asperin a watershed area. Global Journal of Environmental Science Management 3: http://gjesm.net/article_25077.html

UEdA K. 1960. Studies on The Physiology of Bamboo. Bulletin of Kyoto University of Forestry. No. 30, Kyoto.

Virtucio FD \& Roxas CA. 2003. Bamboo Production in the Philippines. Ecosystems Research and Development Bureau, Department of Environment and Natural Resources, Los Baños.

Wang X, Keplinger T, Gierlinger N \& Burgert I. 2014. Plant material features responsible for bamboo's excellent mechanical performance: a comparison of tensile properties of bamboo and spruce at the tissue, fibre and cell wall levels. Annals of Botany 114: 1627-1635.

YU X. 2007. Bamboo: Structure and Culture. MSc thesis, University of Duisburg-Essen, Essen.

Yu HQ, Jiang ZH, Hse CY \& Shupe TF. 2008. Selected physical and mechanical properties of Moso bamboo (Phyllostachys pubescens). Journal of Tropical Forest Science 20: 258-263.

Zhou BZ, Mao-Yi F, Xie JZ, Xiao-Sheng Y \& Li ZC. 2005. Ecological functions of bamboo forest: Research and application. Journal of Forestry Research 16: 143-147. 